\title{
Питання психології
}

УДК $159.938 .3: 378$

DOI: $10.33099 / 2617-6858-20-57-4-136-143$

Якимчук I. П. кандидат психологічних наук, доцент, Уманський державний педагогічний університет імені Павла Тичини

https://orcid.org/0000-0002-4627-2066

\section{ПРО ІНДИВІДУАЛЬНО-ПСИХОЛОГІЧНУ ОБУМОВЛЕНІСТЬ МЕХАНІЗМІВ ПСИХОЛОГІЧНОГО ЗАХИСТУ У ПРОФЕСІЙНІЙ ДІЯЛЬНОСТІ ПСИХОЛОГА ОСВІТНЬОЇ УСТАНОВИ}

У статті обтрунтовується обумовленість психологічних захистів у професійній діяльності практичних психологів закладів освіти їхніми індивідуально-психологічними особливостями. Змістовно описано особливості функиіонування конкретних психологічних захистів у практичній діяльності психолога закладу освіти як представника соціономічної професії.

Ключові слова: механізми психологічного захисту; професійна діяльність; практичні психологи; заклади освіти; індивідуально-психологічні особливості.

\section{Вступ.}

Актуальність теми. Професійна діяльність характеризується великою кількістю ситуацій, що викликають тривогу i занепокоєння, і щоб впоратися із цими почуттями, працівник активізує психологічний захист. Як психічний феномен психологічний захист актуалізований на усіх рівнях психічної організації суб'єкта, однак, його феноменологічний прояв має виражену особистісну приналежність. На думку деяких авторів, саме особистісні структури, механізми, патерни поведінки перебувають в основі психологічного захисту [1]. Сучасних дослідників психологічного захисту особливо цікавить питання про особистісну типовість репертуару захисних механізмів, його стійкості і відтворюваності у різних життєвих ситуаціях. У зв'язку із цим виникає проблема індивідуальної широти захисного репертуару особистості, детермінації вибору особистістю того чи іншого способу захисту, особистісної регуляції захисної поведінки.

Мета статті - обгрунтування обумовленості психологічних захистів у професійній діяльності практичних психологів закладів освіти їхніми індивідуально-психологічними особливостями.
Завдання статті - змістовно описати особливості функціонування конкретних психологічних захистів у практичній діяльності психолога закладу освіти як представника соціономічної професії.

Теоретичне підгрунтя.

Узагальнюючи існуючі дослідження із визначення зв'язку особистості i психологічного захисту, можна виокремити такі факти, що впливають на формування i функціонування психологічного захисту. По-перше, розвиток психологічного захисту особистості обумовлюється специфічною мотивацією у формі різних типів тривоги [2]. По-друге, психологічний захист формується у загальній структурі особистості у вигляді набору захисних механізмів під впливом таких чинників, як темперамент; стрес раннього дитинства; захисні механізми, використовувані батьками; моделі поведінки 3 особистого досвіду використання захисних механізмів [3]. По-третє, механізми захисту можуть бути примітивними і зрілими [10]. Таким чином, дослідники сходяться на думці, що специфіка інтерпретації важких ситуацій, а так самозастосування тих чи інших технік може бути психологічним маркером різних типів особистості.

Проведені А.Г. Петровою дослідження феномену психологічного захисту підтвердили наявність зв'язку між рисами 


\section{Питання психології}

особистості і вибором того чи іншого захисного механізму. Крім цього, було виявлено низку особливостей динаміки захисних механізмів та їхньої структури у залежності від пережитого особистістю стресового досвіду та професії. Виявилися загальні тенденції серед різних груп обстежуваних між об'єктивною адаптованістю суб'єктів та особливостями структури захисних механізмів, що вказує на значну роль психологічного захисту в адаптації особистості. В результаті цих досліджень також було виявлено, що кількість використовуваних особистістю захисних механізмів визначає рівень піi психологічного благополуччя та адаптивності. Підвищення дезадаптації особистості позначається на структурі захисних механізмів таким чином: змінюється кількість застосовуваних механізмів, число i жорсткість зв'язків у структурі психологічного захисту. Подальші дослідження феномену психологічного захисту дозволили виявити певні стилі захисного поведінки зі специфічними когнітивними, поведінковими та емоційними складовими. Крім того, проведене дослідження підтвердило, що вибір механізму психологічного захисту залежить як від зовнішніх чинників, так і від внутрішніх, до яких належать стійкі характерологічні особливості [8].

Сучасне вивчення детермінації поведінки у важких ситуаціях ведеться у декількох напрямках. Р.Лазарус і С.Фолкмен підкреслюють роль когнітивних конструктів, що обумовлюють способи реагування на життєві труднощі. П.Коста i Р.Маккрей роблять акцент на вплив особистісних перемінних. У.Лер і Г.Томе приділяють велику увагу аналізу важких ситуацій, припускаючи сильний вплив контексту ситуації на вибір стилю реагування. Інтерпретація феноменів захисту та упорання також пов'язана із вивченням індивідуальної поведінки у контексті проблеми стресу. Висновки про те, що людина, володіючи певним набором особистісних рис, в стресовій ситуації буде використовувати відповідні захисні механізми, є дуже важливими. Це пов'язано iз тим, що індивідуально-психологічні особливості відіграють значну роль у професійній діяльності як на етапі вибору професії, так і на етапі ऑii освоєння i реалізації. Тому можна припустити наявність зв'язку між індивідуальнопсихологічними особливостями психолога, які позитивно впливають на здійснення професійної діяльності, і вибором моделі тієї чи іншої захисної поведінки у складних ситуаціях професійної діяльності.

\section{Методи дослідження.}

Для досягнення мети i реалізації завдання дослідження було використано низку теоретичних методів - аналіз, синтез, узагальнення, порівняння і систематизація наукових джерел у галузі психології із проблеми психологічних захистів особистості.

\section{Результати і обговорення.}

У сучасних дослідженнях ролі психологічного захисту у професійній діяльності спостерігається два підходи: розгляд чинників і ситуацій, які викликають психологічний захист особистості; розгляд психологічного захисту з точки зору її ролі у формуванні професійних деструкцій особистості професіонала. Так, з точки зору першого підходу система психологічного захисту визначається як потужна адаптаційна структура особистості, яка забезпечує здатність людини виробляти адекватні умовам способи поведінки i діяльності на основі властивих йому рис, а також гармонізувати внутрішній стан людини.

Аналіз літератури за тематикою професійного шляху особистості дозволяє виокремити ті аспекти професійної діяльності, які визначаються дослідниками як найбільш проблемні, конфліктні для працівника. Умовно чинники, що провокують різні форми психологічного захисту, можна розділити на групи: організаційні (безпосередньо пов'язані із виробничою діяльністю), та особистісні (зумовлені особливостями самого суб'єкта 


\section{Питання психології}

праці). Характер, інтенсивність переживання буде залежати від вираженості напруги i суб'єктивного переживання потреби у вирішенні проблеми; від об'єктивних параметрів ситуації (неструктурованість умов, засобів, цілей); від представленості структури ситуації у свідомості особистості; від власних можливостей (від досвіду вирішення подібних ситуацій, від впевненості у здатності вирішити будь-яку проблему), так само, як і способи психологічного захисту, що застосовуються у таких ситуаціях, багато у чому визначаються індивідуальнопсихологічними особливостями працівника.

Узагальнюючи концепції, що пояснюють взаємовідносини захисних механізмів і копінг-процесів, Н.В. Родіна зазначає, що обидва ці процеси починають функціонувати в умовах, коли людина перебуває у стані стресу i/aбо іiі самооцінка перебуває під загрозою і характеризуються зміною мислення, емоцій і поведінки. Тобто вони виконують подібні функції - адаптацію до важких життевих ситуацій та активізуються у ситуаціях порушення психологічної рівноваги. При цьому більш зрілі психологічні захисні механізми і більш продуктивні копінг-стратегії сприяють ефективній адаптації особистості у стресових ситуаціях, тоді як адаптивна роль незрілих захисних механізмів i непродуктивних копінг-стратегій певною мірою $є$ низькою, крім того, вони можуть призводити до дезадаптації [9].

Більшість авторів, що досліджують питаннями психологічного захисту в аспекті професійної діяльності, відзначають іiі негативний вплив на розвиток професіонала. Особливо підкреслюється роль психологічного захисту у розвитку професійних деформацій. До однієї 3 психологічних детермінант професійних деструкцій належать різні форми психологічного захисту, захисні механізми (заперечення, раціоналізація, витіснення, проекція, ідентифікація, відчуження). Професійні деформації також формуються під впливом професійної ролі, коли у людини змінюються ті або інші властивості особистості, виникає професійний тип особистості, який проявляється і поза професійною сферою. С.П. Безносов, Р.М. Грановська, Л.М. Корнєєва, А.К. Маркова, Є.Ф.Зеер, В.С. Орел відзначають, що найбільшою мірою професійні деформації розвиваються у представників соціономічних професій, які постійно взаємодіють із людьми: лікарів, педагогів, психологів, працівників сфери обслуговування і правоохоронних органів, держслужбовців, керівників, підприємців та iн.

В літературі також представлені дослідження професійних деформацій психологів. Так, Д.Г. Трунов розглядає чинники, механізми і результати зміни особистості практичного психолога під впливом професійної діяльності [13, С. 1216.]. Ці зміни можна розділити на позитивні наслідки, які вписуються у поняття «особистісного зростання» (більш глибоке розуміння себе, людей i подій, що відбуваються; аналіз життєвих ситуацій; здатність до рефлексії; навички продуктивного подолання кризових i психотравмуючих ситуацій; комунікативні навички; протистояння чужому впливу; саморегуляція; здатність до прийняття та емпатії; ширший погляд на світ, толерантність до «інакомислячих»; пізнавальний інтерес), і негативні - тобто «професійну деформацію» (проектування негативної проблематики на себе i своїх близьких; нав'язлива діагностика себе i оточуючих; консультування оточуючих; прийняття ролі «вчителя»; зайвий самоконтроль, гіперрефлексія і втрата спонтанності; idea fixe - «робота над собою»; раціоналізація, стереотипізація і зменшення чутливості до живого досвіду; насичена розмова; емоційна холодність; цинізм). Аналіз описаних ним змін особистості психологів під впливом професійної діяльності дозволяе припустити, що в основі деструкцій перебувають такі механізми захисту, як раціоналізація, відчуження, проекція. 


\section{Питання психології}

У науковій літературі представлено дослідження особливостей системи психологічного захисту у представників різних професій, описано деякі закономірності формування комплексів захисних механізмів під впливом особливостей професійної діяльності [11]. Так, за даними Л.Ю. Субботіної, існує така залежність: чим вище стресогенний досвід особистості, тим менша кількість захисних механізмів і тим 3 малою частотою вона їх використовує. Це виражається також у зменшенні зв'язків між ними i появою діадних об'єднань механізмів при розпаді загальної єдиної структури захисту. У нормальних умовах у людини функціонує кілька захисних механізмів, які об'єднуються у систему, а велика кількість зв'язків дозволяе варіювати власну поведінку у залежності від ситуації. Так, у представників системи «людина - людина», яка передбачає більшу варіативність поведінки, у структурі психологічного захисту удвічі більше зв'язків між захисними механізмами, ніж у представників інших систем.

У контексті досліджуваного питання Л.Ю. Субботіною встановлено певний зв'язок психологічного захисту із феноменом психічного вигорання [12]. Як зазначає вчена, зростання рівня вигоряння у вчителів призводить до актуалізації системи психологічного захисту, чим більш яскраво представлено вигоряння, тим більш стабільним $є$ психологічний захист особистості, i тим більш шаблонними стають моделі поведінки педагогів. При високому рівні психічного вигорання механізми захисту є активними, але вони не виконують свою захисну функцію, тобто не сприяють зниженню тривожності. Виявлено взаємний вплив вигоряння і психологічного захисту на адаптаційний рівень особистості i стан тривоги. За результатами пї дослідження виявлено захисні комплекси, характерні для певних етапів професійного розвитку вчителів. Так, при стажі роботи до 3 років представлено три захисних комплексу: регресія - придушення- компенсація - психоемоційне заміщення, виснаження - особистісне віддалення; проекція - компенсація - реактивне утворення. Для вчителів зі стажем роботи від 10 до 15 років характерним $\epsilon$ використання трьох захисних комплексів: раціоналізація - проекція-заперечення; компенсація - реактивне утворення; раціоналізація - придушення. Для вчителів зі стажем роботи понад 20 років характерним $\epsilon$ використання таких захисних комплексів: зсув - регресія - компенсація - придушення; реактивне утворення - раціоналізація. Єдиним механізмом, що впливає на рівень адаптації на цьому етапі професіоналізації, $\epsilon$ придушення. Саме він сприяє усуненню дискомфорту. Таким чином, доводиться значна роль психологічного захисту як адаптаційної системи у професійній діяльності, яка забезпечує зняття емоційної напруги i може запобігати дезорганізації поведінки у разі зовнішніх або внутрішніх конфліктів.

Діяльність психолога як представника соціономічної професії має низку особливостей, які висувають особливі вимоги до системи його психологічного захисту. Діагностична робота поділяється на «науково-практичну» і «науководослідницьку». Завдання першої встановити певні закономірності психічного розвитку. Мета другої - відповісти на конкретне питання у практичній діяльності, виявити причини конкретного психологічного явища або порушення. При цьому діагностика причин не $\epsilon$ для практичного психолога самоціллю, основне завдання - розробка рекомендацій щодо психічного розвитку і корекції особистості. Черговим напрямком діяльності практичного психолога $\epsilon$ психокорекційна та розвивальна робота. Остання спрямована на створення соціально-психологічних умов для цілісного розвитку особистості. Психокорекційна у свою чергу спрямована на вирішення конкретних проблем навчання, поведінки або психічного самопочуття в процесі розвитку особистості. Консультативна робота і просвіта є третім 


\section{Питання психології}

напрямком д діяльності практичного психолога і спрямована на учнів, педагогів та батьків учнів. В усіх учасників освітнього процесу спостерігається стійкий інтерес до психологічних знань. Консультативна робота практичного психолога спрямована на учнів та їхніх батьків, а також колегпедагогів. Ще один напрямок діяльності практичного психолога - соціальнодиспетчерська діяльність, спрямована на забезпечення отримання дітьми, їхніми батьками та педагогами соціальнопсихологічної допомоги, яка виходить за межі функціональних обов'язків i професійної компетентності психолога в освіті. Особливості професійної діяльності практичного психолога визначаються такими чинникаи, як висока інформаційна насиченість, робота iз негативними емоціями учасників освітнього процесу, висока моральна відповідальність за результат роботи, часте виникнення стресових ситуацій, багатозадачність, неможливість алгоритмізації діяльності, несформульованість оціночних критеріїв діяльності та ін. Крім цього, практичний психолог закладу освіти як співробітник організації перебуває у постійній взаємодії iз колегами-педагогами та керівництвом, що вимагає високої комунікативної компетентності та адаптивності.

Основна функція психологічного захисту особистості - регуляція емоційного стану суб'єкта та адаптація його до умов i змісту діяльності. Оскільки психологічна захист виконує функції, необхідні для ефективного виконання професійної діяльності практичного психолога, він може бути компонентом його психологічної системи діяльності. Основними структурними компонентами діяльності $\epsilon$ такі психологічні утворення, як мета, мотивація, інформаційна основа, прийняття рішень, програма діяльності, індивідуальнопсихологічні властивості суб'єкта, психічні процеси, а так само механізми контролю i корекції.

Психологічний захист може мати різну ступінь представленості у системі професійної діяльності. Так, при реалізації консультативного, психокорекційного і розвивального напрямків діяльності, робота i3 психологічної захистом учасників освітнього процесу, тобто учнів, їхніх батьків і педагогів, які є по суті клієнтами практичного психолога, є основною метою його діяльності на етапі формулювання запиту i подальшого опрацювання проблематики.

Ще із часів 3.Фрейда проблема опору посіла центральне місце у теорії і практиці психотерапії і консультування. Майже в усіх концепціях опір розглядається як перешкода психологічної роботи. У деяких концепціях він вважається, якщо не причиною психологічних проблем людини, то їхнім «прикриттям» i перешкодою для роботи iз ними. Початок процесу консультування, як правило, викликає тривогу, оскільки людина відчуває, що іiі світогляд, система оцінок може бути зруйновано зовнішнім впливом. У цьому сенсі опір - форма прояву природного захисту людиною, спроба зберегти звичний спосіб існування [4; 14]. 3 боку практичного психолога робота 3 опором клієнта $\epsilon$ емоційно витратним аспектом діяльності, який вимагає регуляції власної поведінки i емоцій, що, у свою чергу, є неможливим без участі системи психологічного захисту.

\begin{tabular}{cccr}
\multicolumn{2}{c}{ Енергетичною } & основою & будь-якої \\
діяльності & $\epsilon$ & мотивація. & Вплив
\end{tabular} психологічного захисту на мотивацію діяльності полягає у тому, що кожен фахівець орієнтований на самозбереження у діяльності, на вибудовування роботи 3 оптимальним балансом вкладених сил i прогнозованого результату. Таким чином, психологічний захист сприяє адаптації ресурсів фахівця до завдання, яке поставлене перед ним.

Для досягнення поставленої мети необхідна інформація. Сукупність даних являе собою інформаційну основу діяльності. У самому визначенні захисного механізму як процесу інтрапсихічної адаптації особистості під дією підсвідомої переробки інформації, що надходить, 


\section{Питання психології}

закладено вплив психологічного захисту на якість одержуваної інформації [5]. Психологічна система вбудовується у цей структурний компонент на рівні окремих механізмів. Так, наприклад, механізм проекції відіграє важливу роль в процесі консультування. У ситуації консультування не може відбуватися адекватна емоційна взаємодія без прийняття до уваги перенесення і контрпереносу. Транспозицію здійснює клієнт щодо консультанта (перенесення) і консультант щодо клієнта (контрперенос) [6]. В основі перенесення $\epsilon$ механізм проекції. У консультуванні цінність перенесення $є$ достатньо великою. Воно дозволяє зрозуміти, яким чином ранній досвід клієнта, пов'язаний зі значущими особистостями (батьки, близькі), впливає на реакції сьогодення. Контрперенос є настільки ж універсальним явищем у психологічному консультуванні, як і перенесення. Незалежно від зрілості особистості самого консультанта, він людина, i неодмінно має недозволені внутрішні конфлікти. Болючі теми i породжують контрперенос, якщо клієнт мимоволі їх торкається. C.J. Gelso i B.C. Fretz розрізняють широке i класичне визначення контрпереносу. Широке визначення охоплює усі емоційні реакції консультанта на клієнта [15]. До контрпереносу тоді належать i цілком природні реакції консультанта, не пов'язані
3 його внутрішніми конфліктами. Класичне визначення характеризує контрперенос як відповідну реакцію на перенесення клієнта. На думку М.Балінта, відчуття, які консультант відчуває по відношенню до клієнта, є частиною проблематики клієнта [6]. Іншими словами, те, що відчуває практичний психолог в процесі консультування, може виявитися частиною комунікації клієнта (як усвідомленої, так і несвідомої). На основі інформації формулюється програма діяльності i приймаються рішення. 3 огляду на високу моральну відповідальність практичного психолога перед клієнтом за результат роботи ці етапи діяльності пов'язані із переживанням почуття тривоги, хвилювання практичного психолога.

\section{Висновки.}

Таким чином, система психологічного захисту спрямована на зниження тривоги i стабілізацію психоемоційного стану практичного психолога закладу освіти. Найбільш повно психологічний захист представлен у підсистемі професійно важливих якостей, оскільки вона $\epsilon$ вбудованої у структуру його особистості. Взаємини між особистістю і психологічним захистом мають взаємний характер механізми захищають особистість, а особистість визначає, які механізми буде використано для захисту.

\section{Список використаних джерел}

1. Бассин Ф.В. Проблема психологической защиты /Ф.В. Бассин, М.К.Бурлакова, В.Н. Волков// Психологический журнал. - 1988. - №3. - С. 30-41.

2. Долгова В.И., Кондратьева О.А. Психологическая защита / монография. - М.: Издательство Перо, 2014. - $160 \mathrm{c}$.

3. Защитная система личности и стресс / Коллективная монография. Под ред. Е.В. Куфтяк. - М.: Мир науки, 2017. - 158 с. Режим доступа: http://izd-mn.com/PDF/18MNNPM17.pdf

4. Зливков В.Л. Почую лише те, що схочу, або декілька слів про психологічний захист /В.Л. Зливков// Людина і світ. - 1990. - №3. - С. 22-28.

5. Киршбаум Э.И. Психологическая защита / Э.И. Киршбаум, А.И. Еремеева. - М.: Смысл, 2000. $-181 \mathrm{c}$.

6. Кочюнас Р. Основы психологического консультирования / Р.Кочюнас. - М.: Академический проект, 1999. - $240 \mathrm{c}$.

7. Ложкін Г.В. Психологія: терміни, поняття, визначення: словник-довідник / Г.В.Ложкін, І.Я. Коцан, В.А. Бараннік, В.В. Подляшаник; за заг. ред. Г.В. Ложкіна. - Луцьк: Волин. нац. ун-т ім. Л. Українки, 2011.- $188 \mathrm{c}$. 


\section{Питання психології}

8. Петрова А.Г. Психологическая защита как профессионально важное качество педагоговпсихологов в процессе профессионализации: дисс... канд. психол. наук /А.Г. Петрова// Ярославский государственный университет им. П.Г. Демидова. - Ярославль, 2014. - 250 с.

9. Родіна Н.В. Психологія копінг-поведінки: системне моделювання: дис. ... д-ра психол. наук / Н.В. Родіна. - К., 2013. - 504 с.

10. Романова Е.С. Графические методы в практической психологии / Е.С.Романова. СПб.: Речь, 2002. -416 c.

11. Субботина Л.Ю. Психологическая защита и стресс / Л.Ю. Субботина. - Харьков: Гуманитарный Центр, 2013. 230 с.

12. Субботина Л.Ю. Психология защитного поведения: монография / Л.Ю.Субботина. Х.: «Гуманитарный центр», 2013. - 300 с.

13. Трунов Д.Г. Профессиональная деформация практического психолога /Д.Г.Трунов// Психологическая газета. - 2003. - № 1. - С.12-16.

14. Шулдик Г.М. Механізми психологічних захистів у студентської молоді /Г.М.Шулдик// Науковий вісник Херсонського державного університету. Серія: Психологічні науки. Випуск 2. Том 2. 2017. - C. 127-131.

15. Gelso C.J. Counseling Psychology / C.J. Gelso, B.C. Fretz. - N.Y.: Holt, Rinehart and Winston, 1992. $-230 \mathrm{p}$.

\section{References}

1. Bassin F.V. (1988) Problema psihologicheskoj zashhity [The problem of psychological protection] /F.V. Bassin, M.K.Burlakova, V.N. Volkov// Psihologicheskij zhurnal. - №3. - S. 30-41 (in Russian).

2. Dolgova V.Y., Kondrat'eva O.A. (2014) Psyhologycheskaja zashhyta [Psychological protection] / monografyja. - M.: Yzdatel'stvo Pero, 2014. - 160 s (in Russian).

3. Zashhytnaja systema lychnosty y stress [Personality protection system and stress] / Kollektyvnaja monografyja. Pod red. E.V. Kuftjak. - M.: Myr nauky, 2017. - 158 s. Rezhym dostupa: http://izdmn.com/PDF/18MNNPM17.pdf (in Russian)

4. Zlyvkov V.L. (1990) Pochuju lyshe te, shho shochu, abo dekil'ka sliv pro psyhologichnyj zahyst [I only hear what I want, or a few words about psychological protection]/V.L. Zlyvkov// Ljudyna i svit. - №3. S. 22-28 (in Ukranian).

5. Kirshbaum Je.I. (2000) Psihologicheskaja zashhita [Psychological protection] / Je.I.Kirshbaum, A.I. Eremeeva. - M.: Smysl. - 181 s (in Russian).

6. Kochjunas R. (1999) Osnovy psihologicheskogo konsul'tirovanija [Psychological Counseling Basics] / R.Kochjunas. - M.: Akademicheskij proekt. - $240 \mathrm{~s}$ (in Russian).

7. Lozhkin G.V. (2011) Psyhologija: terminy, ponjattja, vyznachennja: slovnyk-dovidnyk [Psychology: terms, concepts, definitions: dictionary-reference book] / G.V.Lozhkin, I.Ja.Kocan, V.A. Barannik, V.V. Podljashanyk; za zag. red. G.V. Lozhkina. - Luc'k: Volyn. nac. un-t im. L.Ukrai'nky. - 188 s (in Ukranian).

8. Petrova A.G. (2014) Psihologicheskaja zashhita kak professional'no vazhnoe kachestvo pedagogovpsihologov $\mathrm{v}$ processe professionalizacii [sychological protection as a professionally important quality of educational psychologists in the process of professionalization]: diss... kand. psihol. nauk /A.G. Petrova// Jaroslavskij gosudarstvennyj universitet im. P.G. Demidova. - Jaroslavl'. - $250 \mathrm{~s}$ (in Russian).

9. Rodina N.V. (2013) Psyhologija koping-povedinky: systemne modeljuvannja [Psychology of coping behavior: system modeling]: dys. ... d-ra psyhol. nauk / N.V. Rodina. - K. - 504 s (in Ukranian).

10. Romanova E.S. (2002) Graficheskie metody v prakticheskoj psihologii [Graphic Methods in Practical Psychology] / E.S.Romanova. - SPb.: Rech'. - 416 s (in Russian).

11. Subbotina L.Ju. (2013) Psihologicheskaja zashhita i stress [Psychological protection and stress] / L.Ju. Subbotina. - Har'kov: Gumanitarnyj Centr. 230 s (in Russian).

12. Subbotina L.Ju. (2013) Psihologija zashhitnogo povedenija [The psychology of defensive behavior]: monografija / L.Ju.Subbotina. - H.: «Gumanitarnyj centr». - 300 s (in Russian).

13. Trunov D.G. (2003) Professional'naja deformacija prakticheskogo psihologa [Professional deformation of a practical psychologist] /D.G.Trunov// Psihologicheskaja gazeta. - № 1. - S.12-16 (in Russian).

14. Shuldyk G.M. (2017) Mehanizmy psyhologichnyh zahystiv u students'koi' molodi [Mechanisms of psychological protection in student youth] /G.M.Shuldyk// Naukovyj visnyk Hersons'kogo derzhavnogo universytetu. Serija: Psyhologichni nauky. Vypusk 2. Tom 2. - S. 127-131 (in Ukranian). 


\section{Питання психології}

15. Gelso C.J. (1992) Counseling Psychology / C.J. Gelso, B.C. Fretz. - N.Y.: Holt, Rinehart and Winston. $-230 \mathrm{p}$.

\section{Резюме \\ Якимчук И. П. кандидат психологічних наук, доиент, \\ Уманський державний педагогічний університет імені Павла Тычины \\ ОБ ИНДИВИДУАЛЬНО-ПСИХОЛОГИЧЕСКОЙ ОБУСЛОВЛЕННОСТИ МЕХАНИЗМОВ ПСИХОЛОГИЧЕСКОЙ ЗАЩИТЫ В ПРОФЕССИОНАЛЬНОЙ ДЕЯТЕЛЬНОСТИ ПСИХОЛОГА ОБРАЗОВАТЕЛЬНОГО УЧРЕЖДЕНИЯ}

В статье обосновывается обусловленность психологических защит в профессиональной деятельности практических психологов учебных заведений их индивидуально-психологическими особенностями. Содержательно описаны особенности функиионирования конкретных психологических защит в практической деятельности психолога образовательного учреждения как представителя сочиономической профессии.

Ключевые слова: механизмы психологической защиты; профессиональная деятельность; практические психологи; учебные заведения; индивидуально-психологические особенности.

\section{Summary \\ Yakimchuk I. Candidate of Psychological Sciences, Associate Professor, Uman State Pedagogical University named after Pavel Tychyna \\ ON THE INDIVIDUAL-PSYCHOLOGICAL CONDITIONALITY OF THE MECHANISMS OF PSYCHOLOGICAL PROTECTION IN THE PROFESSIONAL ACTIVITY OF THE PSYCHOLOGIST OF THE EDUCATIONAL INSTITUTION}

Introduction. Professional activity is characterized by a large number of situations that cause anxiety and worry, and to cope with these feelings, the employee activates psychological protection. As a mental phenomenon, psychological protection is actualized at all levels of the mental organization of the subject, however, its phenomenological manifestation has a pronounced personal affiliation. According to some authors, it is personal structures, mechanisms, patterns of behavior that are the basis of psychological protection. Modern researchers of psychological protection are particularly interested in the question of the personal typicality of the repertoire of protective mechanisms, its stability and reproducibility in various life situations. In this regard, there is a problem of individual breadth of the protective repertoire of the individual, the determination of the individual's choice of a particular method of protection, personal regulation of protective behavior.

Purpose. Substantiation of conditionality of psychological protections in professional activity of practical psychologists of educational institutions by their individual psychological features.

Methods. To achieve the goal and achieve the objectives of the study, a number of theoretical methods were used - analysis, synthesis, generalization, comparison and systematization of scientific sources in the field of psychology on the problem of psychological protection of the personality.

Originality. The presented materials can become the basis for consulting and corrective work of psychologists of educational institutions in the system of education and training, the revealed phenomena of deformation of psychological defense in the conditions of professionalization of practical psychologists provide an additional assessment parameter for their professional certification as employees of educational institutions.

Conclusion. The system of psychological protection is aimed at reducing anxiety and stabilizing the psycho-emotional state of a practical psychologist of an educational institution. The most complete psychological protection is presented in the subsystem of professionally important qualities, because it is built into the structure of his personality. The relationship between personality and psychological protection is reciprocal - the mechanisms protect the individual, and the individual determines what mechanisms will be used for protection.

Key words: mechanisms of psychological protection; professional activity; practical psychologists; educational establishments; individual psychological characteristics.

Recelved/Поступила: 08.11.20. 